\title{
Collaboration of Local Development in the Kepulauan Riau Province and Non-Military Threat to Support the Implementation of State Defense
}

\author{
Neng Suryanti Nengsih \\ Lecturer of Government Science Department \\ STISIPOL Raja Haji Tanjungpinang, Raja Haji \\ Fisabilillah Road No.48 Tanjungpinang City- \\ Kepulauan Riau Province \\ Email: suryatra@yahoo.com
}

\author{
Rendra Setyadiharja \\ Lecturer of Government Science Department \\ STISIPOL Raja Haji Tanjungpinang, Raja Haji \\ Fisabilillah Road No.48 Tanjungpinang City- \\ Kepulauan Riau Province \\ Email: rendra_tanjungpinang@yahoo.co.id
}

\begin{abstract}
The formulation of local development does not always measure the threats that will threaten the government, the society and the region. Because the Local Government is sometimes less responsive to both military and non-military threats. Today's threat to a country and a region not only on the military level is clearly the responsibility of the Indonesian National Army and the Indonesian Police. But today's threats have been present in non-military forms of ideological, political, economic, social and cultural fields, which will subconsciously threaten the unity of a country. This study aims to analyze and elaborate between local development and non-military threats, so that there is a synergy between both. This research methodology is done by qualitative approach, with data collecting technique done by documentation study, interview and observation on unit of local government institution, Indonesian National Army and Indonesian Police. The result of this research is the identification of vision, mission, strategic, target and direction of local development policy and synergize with non-military threat and the actors involved as stakeholders as local development actors paying attention to non-military threat to support the implementation of state defense
\end{abstract}

Keywords- Local Development, Local Government, NonMilitary Threats, National Defense

\section{INTRODUCTION}

The existence of Pancasila as the basis of the state and also the Constitution of 1945 as constitution, is a legal and ideological capital that can be a counterweight to the state of Indonesia to face various possibilities and threats. At the age of Indonesia who has climbed 72 years will bring Indonesia as a country that plays an important role in the international political scene where the possibility of anything that could happen that may also threaten the unity and unity of the State of Indonesia as a country. Threats to the State of Indonesia can occur due to the vortex of conflict on the international level that at any time can threaten the security, integrity, unity and unity of the Unitary State of the Republic of Indonesia (NKRI).
Nationally there are many problems that we can see that are non-military threats that occur in Indonesia. Kepulauan Riau Province is one of the Republic of Indonesia whose position is very strategic which is one of the border areas in Indonesia. The strategic location bordering Singapore, Malaysia, Brunei Darussalam, Thailand and the Philippines is a strategic potential as well as a threat to Kepulauan Riau Province. With such a strategic position, it is necessary to carry out proper and comprehensive development planning. In the process of planning the development of the Regional Government in Kepulauan Riau Province is required to prepare a regional development planning document called the Medium Term Development Plan of the Region that will map the regional development for five years. The Regional MidTerm Development Plan of the Kepulauan Riau Province is based on the vision and mission of the elected Regional Head, namely the vision of the H.M. Sani (late) as Governor and H.M. Nurdin Basirun as the elected deputy governor for the term of office 2016-2021. With the vision of "Realization of Kepulauan Riau as a prosperous Malay Land Mother, noble character, environmentally friendly and superior in the maritime field", the development of Kepulauan Riau Province for the next five years will refer to this vision. To realize the vision, the Kepulauan Riau Provincial Government has several missions, namely:

1. To develop the life of a religious, democratic, just, orderly, harmonious and secure society under the umbrella of Malay Culture,

2. Improve economic competitiveness through the development of quality infrastructure, and equitable and improve inter-district / city connectivity,

3. Improve the quality of education, skills, and professionalism of human resources so as to have high competitiveness,

4. Improve health status, gender equality, poverty handling and social welfare problems, 
5. Continuing the development of maritime-based economy, tourism, agriculture to support the acceleration of economic growth and reduce regional disparities and improve food security,

6. Improving the conducive economic climate for investment activities (investment) and development of micro, small and medium enterprises,

7. Continuing the development of industry-based economy and trade by utilizing local raw materials,

8. Increase the carrying capacity of quality and environmental sustainability,

9. Developing clean governance, accountability, professional bureaucratic apparatus, discipline with a high work ethic and quality of public service delivery [1]

All of these mission visions should be spelled out in a document called the Medium Term Development Plan of the Region. The Regional Regulation of the Medium-Term Development Plan has been approved by the Kepulauan Riau Provincial People's Representative Council at the plenary session of the Kepulauan Riau Provincial People's Council on 31 October 2016. However, the Kepulauan Riau Provincial People's Representative Council requested the Governor of the Kepulauan Riau Province to fix some matters related to sharpening the Medium-Term Development Plan with superior programs, more concrete programs with the achievement of concrete performance indicators, the need for budget allocation program for the improvement of the Human Development Index in Kepulauan Riau Province, as well as the improvement of transportation facilities within the Kepulauan Riau Province as the region maritime [2). With this Medium-Term Development Plan, it is expected that the development of Kepulauan Riau Province will not only be sectoral in local government institutions, but also synergy with the Indonesian National Army. Therefore it is necessary to strengthen other regulations so that the development programs that have been elaborated in the Regional Medium-Term Development Plan can be synergized with the Indonesian National Armed Forces program to face Non-Military threats.

In the context of regional development, one of the areas that should get attention because it is located in the border region of Indonesia is Natuna Regency. The Natuna Islands is one of the archipelago located in a strategic border area in the northern tip of Indonesia. Natuna Sea is also the main trajectory of various types of foreign ships for world shipping activities, ranging from commercial vessels, fishing vessels and warships. The Natuna Islands area of approximately 2,631 $\mathrm{km} 2$ apart from having a very strategic location for international trade shipping lanes also save millions of natural wealth. Natuna Regency consists of 12 districts: 70 villages and 6 villages spread in 154 islands in Natuna Regency. Among the 154 islands, only 27 islands are inhabited, others are still empty. 97.5 percent of Natuna is the ocean. In the development activities, the local government of Natuna Regency is expected to always cooperate and coordinate well with all elements of regional leadership, especially the Indonesian Army National Air Force, military district command, the Police Resort and other ranks. Especially in terms of security is expected to always keep the community with full togetherness and familiarity [3]

In the context of border areas such as Natuna Regency, one of which is also a region in Kepulauan Riau Province should be required a concept of regional development that synergy between local government and the ranks of the Indonesian National Army. Development in the border area became one of the Nawacita Priority Programs, namely Building Indonesia from the periphery by strengthening the regions and villages within the framework of the Unitary State So far, based on the information obtained, there has been no synergy between development programs at the regional government, either in border areas or in other areas in Kepulauan Riau Province with the Indonesian National Armed Forces institution. Development programs in the border areas as well as other areas in Kepulauan Riau Province should adjust and synergize with non-military threat mapping so we can know which development programs are capable of withholding non-military threats that may occur in the future, and with the existence of synergy, the cooperation relationship between Regional Government and Indonesian National Army will be stronger and stronger especially in the context of running the development.

In addition to the issue of development in the border area, another issue that leads to non-military threats is the existence of smuggling. Cases like this are a non-military threat in the economic dimension. With the rampant cases of smuggling of goods will affect the economy in Kepulauan Riau Province indirectly. A news information sourced from metrotvnews.com states that in the province of Kepulauan Riau is often a smuggling occurrence. Action smuggling in the waters of the province of Kepulauan Riau is a concern of the Indonesian National Army Navy, especially the Main Base of the Indonesian National Army Navy IV. During the year 2017 smuggling action was declared declining since the main base of the Indonesian Army IV Naval Intense patrol and form a rapid reaction team called Western Fleet Quick Response (WFQR). Commander of the Main Base of the Indonesian National Armed Forces of the Navy IV stated that Kepulauan Riau Province is $90 \%$ water territory which is very vulnerable to the emergence of various smuggling acts. The crime is more open because the territory of Kepulauan Riau Province is very strategic adjacent to Singapore and Malaysia. Several cases of smuggling are common and successfully completed by the WFQR Team of the Main Base of the Indonesian National Army IV Navy such as the arrest of MT Vier Harmonie in the Datok Island waters of West Kalimantan which will lead to the Kepulauan Riau Province. This ship carry 900 tons of diesel and was taken away by the skipper along with 9 crew. Another case is the capture of MT Angeline 2 in the North Lagoi waters of Bintan Regency. The ship was arrested for engaging in illegal fuel smuggling with MT Vier Harmonie [4]

In addition to the crime of smuggling, the WFQR Team of Main Base of the Indonesian National Army Navy IV also succeeded in arresting six pirates who will act in the waters of 
the Strait of Melaka in December 2016. 6 pirates arrested WFQR Team Main Base of the Indonesian National Army Fourth Navy while preparing to hijack a tanker . In addition to smuggling and piracy cases, the WFQR Team of the Main Base of the Indonesian National Army of the Navy IV also abandoned the sending of illegal migrant workers to Malaysia. The skipper and the crew and their ships carry dozens of migrant workers are secured at the Post of the Indonesian National Army of Lagoi Bintan. In addition, several other criminal acts were also captured by the WFQR Team of the Main Base of the Indonesian National Army IV to April 2017, namely the smuggling of 10,400 non-customs cigarette slopes to Kijang Island, Kepulauan Riau Province. With the success of the WFQR Team of the Primary Base of the Indonesian National Army Navy IV, it is a blame for some crimes on the one hand to be regarded as an accomplishment from the military side. But the big question is why these crimes happen. This is one of the causes is the weakness of development planning at the Regional Government related to ports and free trade that caused various non-military threats. Number of smuggling of goods and also including people, because of weakness of economic development policy and labor which cause society to seek shortcut by doing evil. This is what the local government should be aware of as to how these cases do not occur. One of the steps is to map the regional development in accordance with the threats that are the various crimes described above. With the various problems above, it is necessary to unify the concept, especially in regional development in Kepulauan Riau Province in order to face the threat of Non Military in order to support the implementation of state defense. The unification of the concept must be scientifically analyzed through a study, so that the unification of the concept becomes a concept for the synergy of regional development in Kepulauan Riau Province to face the threat of non-military in order to support the implementation of state defense. It is hoped that the scientific study can create a boundary which then becomes a unified concept that is implemented in the regional development order and able to be revitalized by Non-Military threat. Usefulness of this study will be able to unite Local Government and the Indonesian National Army as an actor who runs the development in Kepulauan Riau Province.

\section{THEORETICAL FRAMEWORK}

\section{A. Concept of Development}

Development according to the explanation Wrihatnolo and Nugroho [5] can simply be interpreted as a measure of changes in the level of welfare measurably and naturally. Changes in the level of well-being are determined by the dimensions of economic, social, political and legal definitions. The measurable change is determined by the dimensions of that change in economic, social, political and legal definitions. The natural change is the institutional change in the social wake of the human group. Only natural changes can ensure consistent structural change.
Conceptually development is a paradigm that is always called by the development paradigm or developmentalism. Bastian [6] explains that the development paradigm is a perspective on a development problem that is used in the development of development in terms of development both as a process and as a method to achieve improvement of human life quality and people's welfare.

Bastian [6] goes on to explain that the development paradigm Indonesia experienced growth ranging from the paradigm of growth (growth paradigm), then shifting the paradigm of welfare (welfare paradigm) or in another sense referred to as the basic need paradigm, and the last is the development paradigm centered human(people centered development paradigm).

In the growth paradigm Bastian [6] explains that the role of the government is planning and creating the desired economic growth with a major element of the growth rate of GNP growth and capital investment, planning in this context is the center down or top-down is the weakness of growth paradigm. Because the mechanism of development centers down all the aspirations and interests of the people tend to be ignored, and the elitist tendencies emerged.

Bastian [6] then goes on to explain that economists argue that development is not just defined as growth. Rather it should also pay attention to the fulfillment of basic needs, such as employment and striving, famine eradication, and malnutrition, health care, water supply and housing, therefore Bastian [6] cites the opinion of many experts to explain that for developing countries to shift its development paradigm to the basic needs paradigm. Bastian [6] cited Effendi's opinion that in this development paradigm public service is required, the creation of certain conditions is also required to give equal access to every citizen in obtaining public services. The creation of open and equal service access to every level of society is necessary for equitable distribution of development and public services. Therefore, in developing countries, welfare is determined by how the public gets access to public services.

But Bastian [6] then continues his discussion by borrowing the term Paulo Freire that this paradigm is actually to help people financially or socially just temporarily to combat the symptoms instead of fighting the cause of the problem. With other meanings, that with this paradigm does not encourage the society to become independent which then make the society will become dependence by giving access all public service and social facility, and society become dependency with government.

So on the basis of these weaknesses, then Bastian [6] describes another paradigm born of criticism two development paradigms above, namely the People Centered Development (PCD). PCD as explained by Bastian [6] is a paradigm that is oriented to the development of human quality. The basic assumption of this paradigm is that development must be solely aimed at benefiting people. In addition, Bastian [6] quoted Korten as saying that this 
paradigm allows the public to have an opportunity to develop creative intelligence for their own future and the future of society in general.

The optimization of development will be influenced by how development planning is planned. Sri Mulyani [5] explains the urgency or importance of development planning in a development process as follows,

1. The country of Indonesia is a large country, both in geographic coverage, number and variety of population, efforts to improve and achieve the welfare of the community will experience complex problems and constraints. The role of development planning and development planning institutions becomes a necessity as a need to develop consistent policies, programs and activities in achieving agreed goals.

2. Planning development with all the completeness of the program, the policy will be a waste if not followed by the budgeting process. This is so that the utilization of available resources must be optimal with the budget they have. Therefore, the relationship between planning and development planning and budgeting is increasingly important,

3. Development planning legislation and budgeting must be synergies, hence strengthening the regulation of these two things must be done so that between development planning and budgeting can run optimally.

Furthermore, Wrihatnolo and Nugroho [5] explained that the characteristics of good development planning are:

1. A development plan is an effort that is reflected in a fixed plan. This is reflected in efforts to increase national production, in the form of a positive rate of economic growth,

2. Business reflected in the plan to increase per capita income and a positive growth rate which, after the reduced rate of population growth also shows an increase in per capita income,

3. Enterprises to change the economic structure that encourages the improvement of agrarian economic structure to industrial structure,

4. There is an expansion of employment opportunities,

5. The existence of development arrangements covering income distribution and development among regions,

6. The existence of community economic institution development efforts that support development activities,

7. Efforts to build gradually on the basis of their own ability or national,

8. Continuous efforts to maintain economic stability.

Wrihatnolo and Nugroho [5] also explained that development planning should also be tailored to particular sectors of development. This development planning approach based on the sector of development planning stems from a discussion of the needs of citizens and a development priority based on the country's financial capacity. There are four sectoral sectors which then become the development planning sector namely political, social, and defense of security.

The sectoral sectors of the economy are the development sectors classified into economic development groups covering the sectors of agriculture, mining, manufacturing, electricity, gas, water, building, trade, restaurants and hotels, transportation and communications, communications, finance, corporate services, general government services, social services, and other services [7].

Wrihatnolo and Nugroho [5] then explain the sectoral politics are the development sectors classified into political development groups, covering the sectors of democracy, human rights, law enforcement, regional autonomy, domestic politics and foreign relations. Wrihatnolo and Nugroho [5] continue to explain that social sectoral development is the development sectors classified into education, health, government administration, facilitation of religious and derivative activities, such as health insurance, social security, education guarantee, water supply, hygiene and sanitation facilities, waste management, religious worship facilities, service of life-and-death documents such as birth certificates, identity documents and identity cards.

Furthermore, the sectoral sector of defense is the development sectors classified into the armed forces development group which includes the police force and the armed forces. The development planning of the sectoral sector of defense departs from the history that the security of all citizens is the responsibility of the state as the mandate of the people. On the contrary, the state is the only instrument entitled to mobilize its citizens to be obliged to defend the state Wrihatnolo and Nugroho [5].

All the concepts of development and planning, should be able to actualize as mandated Article 2 of Law Number 25 Year 2004 [8] namely:

1. National Development is organized based on democracy with the principles of togetherness, justice, sustainability, environmental insight, and independence by maintaining a balance of national progress and unity,

2. National development planning shall be arranged systematically, directed, integrated, comprehensive and responsive to changes,

3. The national development planning system shall be organized on the basis of general principles of state administration,

4. The national development planning system aims to:

a. Supporting coordination among development actors,

b. To create the integration, synchronization and synergy both between regions, between space, between time, between government functions and between central and regional,

c. Ensure linkages and consistency between planning, budgeting, implementation and oversight,

d. Optimizing community participation, 
e. Ensure the efficient, effective, equitable and sustainable use of resources.

Furthermore, the regulation of the scope of national development planning is contained in Article 3, 4, 5, 6 and 7 of Law Number 25 Year 2004. The National Development Plan includes the implementation of all macro government functions covering all areas of life in an integrated manner in the territory of the Republic of Indonesia [5].

Bastian [6] National Development Planning consists of development planning which is arranged in an integrated manner by Ministry / Institution and development planning by Local Government according to its authority. Planning to be produced is Long Term Development Plan, Medium Term Development Plan and Annual Development Plan

\section{B. The Concept of Non-Military Threats}

Non-military threats set out from the Non-Military Defense System as intended by Article 7 paragraph (3) of Law No.3 of 2002 [9] on State Defense is a subsystem of the universal people's defense system to deal with non-military threats. Suryokusumo [10] explains that non-military defense is a defense carried out by civilians (not military personnel), using civilian means (not military or military means) to deal primarily with threats, challenges, obstacles and non-military disorders. So to civil society Indonesia is the implementation of non military defense of the nation and the Unitary State of the Republic of Indonesia entrusted and at stake.

The defense of the state of Indonesia in the 21 st century was organized with three main pillars namely the use of defense forces, international cooperation in the field of defense and defense force development. Therefore, the main guidelines for the implementation of defense at the strategic level require policy on the main pillars above, namely the policy of the use of defense force, the policy of defense cooperation and the development policy of defense force [10]

Along with the development of the era and globalization, then the threat of global security raises a new threat, that is a non-traditional threat committed by non-state actors. The threat of non-traditional security was initially a threat to security and public order. But at a certain escalation level, threats can develop to the extent that endangers the safety of the nation [11].

The position of non-military defense in the face of nontraditional threats is based on the subsystem of the People's Defense System (Sishanta). As explained in Article 7 paragraph (3) of Law Number 3 of 2002 on State Defense [8], namely "State Defense System in facing non-military threats puts government institutions outside the defense field as the main element according to the form and nature of threats encountered with supported by other elements of the nation's power ". So Suryokusumo [10] describes non-military defense systems in Sishanta as complementary rather than supplementary, meaning non-military defense systems with military defense systems are components of the Interdependent and Interdependent System of Defense and Equality (Sishankamrata) that complement and complement each other so the two systems are a complete whole of
Sishanta in the face of any threat, both military and nonmilitary.

Speaking non-military defense context, it is necessary to know the concept of non-military force. According Suryokusumo [10] basically non-military forces exist in all areas of human life outside the field of military as in the field of ideology, political, economic, socio-cultural and others. However, according to Suryokusumo [10] because in general the war in various human life the aim is the mastery of human and its institutions that is state, government and territory controlled by it is non military force according to Suryokusumo [10] in his concept of Non Military Defense System A Complementary Defense System on Military Defense in the Universal People's Defense System there are forces in any field in the areas of Ideology, Politics, Economics and Socio-Culture that can be used to support the achievement of the socio-political goals of the country. Furthermore, Suryokusumo [10] explains that non-military force is a general force which is the main factor of national power that is prepared, prepared in such a way that has the capacity to achieve the objectives, among others supporting national politics, preventing any form of non-military aggression at every level, defeating and destroying nonmilitary aggression, and guaranteeing domestic stability.

The dimensions of non-military threats and the various forms and types of threats can be explained in the following figure as explained by Suryokusumo [10]:

1. Ideological Dimension

In this dimension the ever-present threat is a communist threat. But communist ideology, especially in Indonesia as well as globally unpopular, the potential of ideological-based threats still be taken into account. New forms of ideological threats originating from within and from abroad, namely the metamorphosis of communists who have merged into the elements of society, can at times threaten Indonesia.

In addition, in the 2003 White Paper promotes radical groups as one of the real threats to non-military threats. Motives behind the movement can be a pretext of religion, ethnicity, or the interests of the people. At present there are still elements of radicalism that use religious attributes trying to establish a state with other ideologies [10]

\section{Political Dimension}

Suryokusumo [10] explains that the threat of political dimension can be sourced from abroad and within the country. From abroad, the threat of political dimension is carried out by a country by exercising political pressure on Indonesia. Intimidation, provocation or political blockade are forms of non-military threat of political dimension that are often used by other parties to pressure other countries.

Suryokusumo [10] then continued his discussion that politics is the main instrument that can be the determinant of peace or war. Politics can also subvert a government and even destroy the country completely. The threat of separatism is a form of political threat that arises in the country. As a form of political threat, separatism can pursue a pattern of unarmed political struggle and arms struggle. The pattern of unarmed struggle is often pursued to attract the sympathy of the 
international community, therefore separatism is difficult to cope with using military instruments. On the contrary, the threat of armed separatism often has difficulties as a result of politicization, handling by the government by using a military operation approach. This proves that the threat of political dimension has a high level of risk that will threaten the sovereignty, integrity and safety of the nation.

\section{Economic Dimension}

Suryokusumo [10] explains that basically the threat of economic dimension can be grouped into two, namely internal and external. In the context of Indonesia, internal threats can include inflation and high unemployment, inadequate infrastructure, unclear economic systems, inequalities of income distribution and high cost economy, while externally can be in the form of indicators of poor economic performance, low competitiveness, the unpreparedness of the era of globalization and the level of dependency high enough to foreigners.

\section{Social and Cultural Dimensions}

Suryokusumo [10] explains that threats of socio-cultural dimension can be distinguished from threats from within, and external threats. Threats from within are driven by issues of poverty, ignorance, backwardness, and injustice. The issue becomes the starting point of the problem, such as separatism, terrorism, deep-rooted violence, and human-caused disasters. The issue then threatens unity, and national unity, nationalism and patriotism.

In addition Suryokusumo [10] continue his explanation that the threat of socio-cultural dimension in horizontal dimension of tribe, religion, race and intergroup basically arise due to the nature of violence that has been attached. The violent character also encourages crime, including environmental destruction and man-made disasters. These factors are widely processed and produce a domino effect that can weaken the quality of life of the Indonesian nation. The ongoing population growth has resulted in the declining carrying capacity and environmental conditions. Along with that the outbreak of pandemic disease, such as bird flu, dengue fever, HIV / AIDS and malaria is a serious challenge faced in the future.

Concerning external threats in the context of sociocultural dimensions according to Suryokusumo [10] emerged simultaneously with the dynamics occurring in the formal globalization with the penetration of cultural values from abroad that are difficult to be dammed affect the values in Indonesia. One example is the progress of information. With the progress of information interaction society took place in the actual time. So that over time will erode the values of unity and the unity of the nation increasingly urged by the values of individualism.

\section{Dimensions of Information Technology}

Suryokusumo [10] explains that the threat in this dimension is the slow progress of science and technology progress in Indonesia. So Indonesia should depend on other countries. Such dependence has made Indonesia an easy target for world markets and products. If so then the condition of Indonesia will be weak in the international market.
Another challenge described by Suryokusumo [10] is the mindset of the domestic community on the nation's technological works of the nation. Indonesia has always won science olympiads such as mathematics, physics and chemistry, besides Indonesia has human resources in the field of technology. But there is no container that ensures the excitement to build the nation's ability in the field of technology resulting in the current exodus of Indonesian experts to the outside who offer a better life.

6. Dimensions of Public Safety

Suryokusumo [10] explains that Indonesia is in disaster prone areas, natural disasters, transportation safety and famine. Disasters that can occur in Indonesia and pose a threat to public safety can occur purely natural disasters, such as earthquakes, volcano eruptions, and tsunamis. But there are also disasters caused by humans, among others, uncontrolled use of drugs and chemicals, especially other psychotropic drugs that can poison the community, especially young people, either directly or chronically (chronic). Likewise natural disasters caused by natural factors, landslides, droughts, forest fires, and other disasters. In addition, transportation security will also be a threat where public and airline understanding of transport safety is no longer the main thing. With the cheap price has resulted in transportation safety is not a priority.

\section{Dimensions of Law Enforcement Officials or} Legislators

The Ministry of Defense of the Republic of Indonesia in an exposition of working meetings delivered by the Executive Officers of the Kepulauan Riau Province Defense Ministry's Duties of 2017 [12] stated that there is one more dimension that goes into non-military threats, namely the dimensions of law enforcement or legislators. Threats that may occur include duplication of national law, the intervention of others in the judicial process, the morality of law enforcement officials who are deemed to have no integrity, independence of national and customary law, the weakness of law in international negotiations, pressure on the judicial process, foreign interests against non-governmental organizations, intervention of the system of government from foreign parties or interest groups, issues of human rights violations, foreign attempts to control the rule of law of the Republic of Indonesia, and the legal extra-territorial principle of other countries. From all forms of threat it can be seen that the threat to law enforcement is not only coming from the internal state but also from external.

\section{RESEARCH METHODOLOGY}

This research is a qualitative approach. Data collection techniques conducted by documentation studies, interviews and forum discussion groups. Documentation studies are conducted by analyzing the linkages of several documents such as the Kepulauan Riau Provincial Medium Term Development Plan of 2016-2021, the strategic plan of the Regional Government Organization and the Indonesian National Army, as well as reports on activities related to regional development and non-military threats. Interviews 
were conducted with structures to the Regional Government and the Indonesian Armed Forces and related institutions, as well as focus group discussions that were also conducted using local government organizations and the Indonesian National Armed Forces.

\section{RESULTS AND DISCUSSION}

\section{A. The Regional Development Strategy in the Kepulauan Riau province in order to face the threat of Non-Military}

Strategic development of the region can not be separated from the vision of the mission that has been defined in the Kepulauan Riau Provincial Medium Term Development Plan 2016-2021 [13]. The vision of Kepulauan Riau Provincial Government is the realization of Kepulauan Riau as a prosperous Malay Land Mother, noble character, environmentally friendly and superior in the maritime field, the development of Kepulauan Riau Province for the next five years will refer to this vision. To realize this vision, the Kepulauan Riau Provincial Government has several missions: (1) Developing a livelihood of a religious, democratic, just, orderly, harmonious and secure society under the umbrella of Malay Culture, (2) Improving economic competitiveness through the development of quality infrastructure, and flattening and improving inter-district / city connectivity, (3) Improving the quality of education, skills and professionalism of human resources so as to have high competitiveness, (4) Improve health status, gender equality, poverty handling and social welfare problems, (5) Continuing the development of maritime-based economy, tourism, agriculture to support the acceleration of economic growth and reduce regional disparities and increase food security, (6) Improving the conducive economic climate for investment activities and development of micro, small and medium enterprises, (7) Continuing the development of industry-based economy and trade by utilizing local raw materials, (8) Increasing the carrying capacity of quality and environmental sustainability, (9) Developing clean, accountable governance, professional bureaucratic apparatus, discipline with high work ethic and quality public service delivery. Thus all regional development strategies for dealing with non-military threats in this study were analyzed based on threats that fall within the category of non-military threats and based on development strategies developed under the vision and mission of the Kepulauan Riau Provincial Government.

\section{Ideology Dimension}

Non-military threats based on Suryokusumo [10] range in terms of threats in motives relating to religion and radicalism movements. Threats in identified regional development as described in the Kepulauan Riau Province Mid-term Development Plan of 2016-2021 in the political dimension is the quality of human development that is not yet optimal. As data obtained from the Kepulauan Riau Province's Mid-Term Development Plan of 2016-2021, the Kepulauan Riau Province Human Development Index shows a tendency to increase the Human Development Index figure by 2015 by 73.75. It is still considered necessary to be improved. If this is ignored, it will indicate a threat in the form of criminality, radicalism, terrorism, social and economic disparities. So to prevent the existence of these threats, it has several strategies integrated in the development program of Kepulauan Riau Province.

The regional development strategy formulated from the three missions as the result of analysis and findings of the Kepulauan Riau Provincial Medium-Term Development Plan of 2016-2021 [13] is (1) applying the Magrib Mengaji Movement in collaboration with community and / or district institutions, this strategy resulted in an improvement program, , appreciation, practice, and the development of religious values. For the implementation of this strategy, the actors involved in this strategy consist of the main actors and supporting actors. The main actors are the Public Welfare Administration Bureau, the Ministry of Religious Affairs, and the Regional Narcotics Board, while the Indonesian National Army, the Indonesian National Police and the Ministry of Defense are supporting actors. (2). Improve security, peace and order, in the community. This strategy spawned several programs, namely law enforcement and human rights programs, security and public order maintenance programs and prevention of criminal acts, and the development of national insight. the main actors in carrying out the regional development strategy are the National Unity, Politics and Public Protection Agency, the Civil Service Police Unit, the Regional Narcotics Board, the Prosecutor's Office, and the Political Parties. While the Indonesian National Army and the Republic of Indonesia Police and the Ministry of Defense are supporting actors. (3) the next strategy is to provide support for poor families, increase the availability of schools in distric that do not have education units and strengthening the private role. This strategy gave birth to the program of sports improvement program as well as youth, coaching and socialization programs and sports facilities. The main actors of this strategy are the Education Office, the Youth Sports Office, the Regional Narcotics Board, and supporting actors are the Indonesian National Army, the Indonesian Republic Police and the Ministry of Defense. (4). Another strategy is to improve coordination and cooperation in border development. This strategy resulted in the development of border areas. The actors involved as the main actors are the Border Management Agency, the National Unity Board, the Politics and the Protection of Communities and the Regional Narcotics Board, and the supporting actors are the Indonesian National Armed Forces, the Police of the Republic of Indonesia and the Ministry of Defense.

\section{Political Dimension}

In the political dimension, the threats that can occur based on Suryokusumo's explanation [10] may take the form of intimidation, provocation, or political blockade that is often used by others to pressure other countries. Possible threats to threaten regional development in Kepulauan Riau Province as described in the Kepulauan Riau Provincial Medium Term 
Development Plan 2016-2021 [13] in the form of border area development is not yet optimal. Based on data in the Kepulauan Riau Provincial Regional Development Plan 20162021, Kepulauan Riau has 19 outermost islands comprising Karimun 2 islands, Batam City 4 islands, Bintan Regency is 1 island, Natuna regency is 7 islands and Anambas Regency 5 islands. Some crucial things that need attention is the welfare of people in the border area, as well as means of communication, education. This needs to be resolved by strategy in the political dimension. Other issues identified in the Kepulauan Riau Provincial Medium Term Development Plan 2016-2021 [13] are limited fiscal capacity and poor governance. The data notes that the regional financial capacity to finance regional expenditure is relatively small by 2015 . Local revenues and regional financing receipts amounted to 2,637 billion Rupiah. Another problem is the problem of interisland and inter-district and city connectivity. If this issue is not resolved then an indication of a possible threat will occur as described by Suryokusumo [10] on non-military threats of political dimension of disintegration, terrorism, social conflict, radicalism and separatism.

Based on the data contained in the Kepulauan Riau Provincial Medium Term Development Plan 2016-2021 [13], the development strategy formulated by the Kepulauan Riau Provincial Government is (1) to improve security, order, in the community. From this strategy the Kepulauan Riau Provincial Medium Term Development Plan 2016-2021 [13] describes the program as a law enforcement and human rights program and program of kamtibmas maintenance and prevention of crime as well as the program of developing national insight. The main actors in this strategy are the National Unity, Politics and Public Protection Agency, the Civilian Police Unit, the Regional Narcotics Board, the Prosecutor's Office and the Political Parties, and the supporting actors are the Indonesian National Armed Forces, the Police of the Republic of Indonesia and the Ministry of Defense, (2) improve coordination and cooperation in border development. The program generated in this program is the development of border areas. As the main actors are the Border Agency, National Unity Board, Politics and Protection of the Community and Regional Narcotics Board, while supporting actors are the Indonesian National Army, the Republic of Indonesia Police and the Ministry of Defense.

\section{Economic Dimension}

Based on Suryokusumo's [10] explanation that threats in the economic dimension can occur internally and externally, internally can be inflation, high unemployment, inadequate infrastructure, unclear economic system setting, inequality income distribution and high cost economy. Non-military threats in the external economic dimension as described by Suryokusumo [10] are poor economic performance, low competitiveness, uncertainty facing the era of globalization and high levels of dependency on foreigners. Within the Kepulauan Riau Provincial Urban Development Plan 2016-
2021 [13] identified several strategic issues that pose a threat to regional development that will allow non-military threats to emerge in the economic dimension. The strategic issues described in the Kepulauan Riau Provincial Medium Term Development Plan 2016-2021 [13] is that poverty should continue to be lowered. The data notes that the poverty rate in Kepulauan Riau Province although tends to decrease from $8.13 \%$ (137,072 souls) in 2010 to $6.24 \%$ (122,398 souls) by 2015. This condition is higher when compared to the Province of Bangka Belitung is $4.97 \%$. Another strategic issue is high unemployment. Data in the Kepulauan Riau Provincial Regional Development Plan 2016-2021 [13] notes that the open unemployment rate is quite high, at $6.20 \%$ by 2015 . These issues will economically lead to threat indications of weak competitiveness and social and economic imbalances.

Therefore, the strategic development of the area undertaken by the Kepulauan Riau Provincial Government as analyzed based on data from the Kepulauan Riau Provincial Medium-Term Development Plan 2016-2021 [13], in order to deal with non-military threats are (1) The development of transportation access in the context of means of transportation both land, sea, and air, (2) Development and opening of economic access, (3) Increasing labor human resources to international competitiveness, (4) Providing social protection, (5) Empowerment of the poor, (6) post-disaster rehabilitation, (7) Development of fisheries sector productivity, (8) Development of border areas, (9) Conservation of marine natural resources, and (10). Fostering Small and Mediumbased Micro and Small Business.

The synergy between actors must also be built, which in this context are the Transportation, Syahbandar, Navigasi, Port Administration, Coast Guard and Coast Guard Unity and Angkasa Pura in solving transportation and transportation problems. The Department of Manpower, the Ministry of Law and Human Rights of the Immigration Division in terms of resolving labor issues. Community and Village Empowerment Bodies in terms of solving village problems and their potential. Social Services, Women's Empowerment and Child Protection, Fire Brigade, National Search and Rescue Agency, and Regional Disaster Management Agency in resolving domestic conflicts, natural disasters, poverty and other hazards. Department of Strength and Fishery, Customs, Navigation and Unity of Sea and Coast Guard in terms of solving smuggling, illegal fishing and sea robbery problems. Department of Agriculture, Forestry and Livestock and Food Security Agency in terms of solving problems in the field of food crisis. Border Management Agency and National Unity, Politics and Protection Agency in solving social conflict problems and especially border areas. While all government organizations are supported by the Indonesian National Army, the Republic of Indonesia Police and the Ministry of Defense as supporting actors.

\section{Social Dimensions of Culture}

Suryokusumo [10] explains that non-military threats in the socio-cultural dimension are threats in the form of issues of poverty, ignorance, backwardness, and injustice. The issue 
is the starting point of separatism, terrorism, and the inherent violence and disaster caused by human actions. In addition to this threat of form, it can also be shaped like an outbreak of infectious diseases, such as bird flu, HIV-AIDS, Sars, and so on.

As promulgated in the Kepulauan Riau Provincial Medium Term Development Plan 2016-2021 [13], there are several strategic issues that will indicate the birth of nonmilitary threats in the socio-cultural field, namely equality and gender justice is still low. Kepulauan Riau Provincial Medium Term Development Plan 2016-2021 [13] notes that the Kepulauan Riau Province Gender Development Index in 2014 reached 93.20 and the Gender Empowerment Index of 2013 was 60.79. Gender Development Index of Kepulauan Riau Province is still lower than ideal condition that is toward number 100. This strategic issue will give birth threat like human rights gap and social conflict in the form of discrimination. Another strategic issue is the degree of public health is not optimal. The Kepulauan Riau Provincial Medium Term Development Plan 2016-2021 [13] notes that the Life Expectancy Rate of 2015 is 69.41 , malnutrition by $0.46 \%$ and the prevalence of infectious diseases and infectious transmitters is also high. An indication of the threat from this strategic issue is the presence of infectious diseases that will endanger the potential and quality of human life in Kepulauan Riau Province.

Thus, the regional development strategy of Kepulauan Riau Province to face non-military threat in the socio-cultural dimension is (1) Strengthening of religious values, (2) Strengthening national insight, (3) Just and transparent law enforcement, (4) Political education to society (5) Optimization of health services, (7) Village empowerment and development, (8) Gender mainstreaming, (9) Protection of women and children, (10) Social security facilitation, (11) Disaster management, (12) Strengthening of border areas.

The main actors involved in strengthening this strategy are the Ministry of Religion and National Unity, Politics and Public Protection in solving the problem of religiosity and Public Order and Security, as well as national insight. Health Office in solving health crisis problems. Department of Transportation, Syahbandar, Navigation, Port Administration, Coast Guard Unity and Coastal, and Angkasa Pura in terms of solving transportation and transportation problems. The Department of Manpower, the Ministry of Law and Human Rights of the Immigration Division in terms of resolving labor issues. Community and Village Empowerment Bodies in terms of solving village problems and their potential. Social Services, Women's Empowerment and Child Protection, Fire Brigade, National Search and Rescue Agency, and Regional Disaster Management Agency in resolving domestic conflicts, natural disasters, poverty and other hazards. Department of Strength and Fishery, Customs, Navigation and Unity of Sea and Coast Guard in terms of solving smuggling, illegal fishing and sea robbery problems. Department of Agriculture, Forestry and Livestock and Food Security Agency in terms of solving problems in the field of food crisis. Border Management Agency and Kesbangpollinmas Department in terms of solving social conflict problems and especially border areas. All of these actors are supported by the Indonesian National Army, the Republic of Indonesia Police and the Ministry of Defense.

\section{Dimensions of Public Safety}

According to Suryokusumo [10], non-military threats in the public safety dimension are threats in the form of natural disasters that are caused by natural processes of nature. But in addition there are also disasters caused by human activities that is not controlled use of drugs, chemicals, and psychotripika that affect the mentality and attitude of humans in a country. The exposure of the population without the development of the Ministry of Defense of the Republic of Kepulauan Riau Province [13] adds a form of non-military threat in the public safety dimension in the form of terrorism, food insecurity, thuggery, environmental pollution, drug crime as well as the limitations of social infrastructure.

Based on the data presented in the Kepulauan Riau Provincial Regional Development Plan 2016-2021 [13], the stretagic issue that can generate indications of non-military threats is the issue of food crisis and food insecurity. The Kepulauan Riau Provincial Medium Term Development Plan 2016-2021 [13] describes data that the situation of food vulnerability in Kepulauan Riau Province is high. By 2015, there are no sub-districts that have priority 1 and 2 which are very vulnerable to food in 2015 , but $6.98 \%$ ( 3 sub-districts) are in priority 3 and $23.26 \%$ (10 districts) is still a priority 4 . Priorities 3 and 4 are the values for sub-districts that have vulnerability and food insecurity and nutrition in moderate condition. Other strategic issues that pose a threat as described in the Kepulauan Riau Provincial Regional Development Plan 2016-2021 [13] are Terrorism and heresy, especially in border areas, Terrorism yag entering on certain transportation lines, smuggling of narcotics and drugs, thuggery and social unrest, infectious diseases, social gaps, and natural disasters.

The strategy undertaken by the Kepulauan Riau Provincial Government in regional development to face nonmilitary threats as described in the Kepulauan Riau Provincial Medium Term Development Plan 2016-2021 [13] is (1) Increasing understanding of religious values, (2) Law enforcement, (3) Increasing national insight, (4) Political education to society, (5) Improvement of transportation and transportation line management, (6) Improved youth and sports activities, (7) Improvement of health and pharmaceutical programs, (8) Improvement of child and women protection programs and gender mainstreaming, (9) Social rehabilitation, social empowerment and disaster management, (10) Improvement of food quality, (11) Optimization of border area management.

The main actors in regional development synergies and non-military threats are the Ministry of Religious Affairs, the Bureau of Public Welfare Administration and the National Unity, Politics and Protection of Communities and political parties in matters relating to the issue of religious issues and national insight as well as political education to the public. Prosecutor's Office, and the Ministry of Justice and Human 
Rights and the Civil Service Police Unit in the context of law enforcement. Department of Transportation related to the improvement of transportation and transportation line management. The Office of Youth Sports and the Education Office on issues related to youth and sports activities. Health Office concerned on health and pharmaceutical issues, and in cooperation with the Regional Hospital. Social Service, the Office of Women's Empowerment and Child Protection, which deals with issues of social rehabilitation and social empowerment. Regional Disaster Management Agency, National Search and Rescue Agency on the issue of natural disasters. Food Security Agency and Agriculture, Forestry and Estate Crops Office on food security issues, and Border Management Agency in relation to border area issues. The supporting actors are still supported by the Indonesian National Army, the Republic of Indonesia Police and the Ministry of Defense.

\section{Dimension Technology Information}

Based on the exposure conveyed by the Ministry of Defense of Kepulauan Riau Province [12] explained that the form of non-military threat in the information technology dimension is in the form of cyber crime, slow transfer of science and technology, technology dependence, computer virus spread, and negative impact of information technology and telecommunication. Based on the identification of nonmilitary threats that would threaten regional development in the dimension of information technology as described in the Kepulauan Riau Provincial Medium Term Development Plan 2016-2021 [13] namely cyber crime, the slow spread of information technology and communications due to the quantity and quality of infrastructure that has not adequate. In addition, inter-island connectivity and between districts and cities are still experiencing gaps. So it affects the development of information technology. This condition will indicate the birth of social and economic disparities as well as information and also discrimination.

Therefore, to overcome the indications of the threat, the Kepulauan Riau Provincial Government has a regional development strategy contained in the Kepulauan Riau Provincial Medium Term Development Plan 2016-2021 [13], namely (1) increasing the capacity of government apparatus in public services, network management and utilization egovernment application of the scope of government, (2) improving encryption services on all regional devices. From the two strategies formulated by the Kepulauan Riau Provincial Government, it produces several programs, namely (1) e-government development programs, (2) public information and communication development programs, (3) codes and telecommunications programs.

From these programs. Then the actors who must be involved in the development of the region consist of main actors and supporters. The main actors in this case are the Office of Communication and Information and Information Commission. While the supporting actors are the Indonesian
National Army, the Republic of Indonesia Police and the Ministry of Defense.

\section{Dimensions of Law Enforcement}

Several non-military threats in the dimensions of legislators and law enforcement officials as described in the exposure of conveyed by the Ministry of Defense of Kepulauan Riau Province [12] can be a matter of morality of law enforcement apparatus, duplication of national law, intervention of others in judicial process, independence of national law and custom, the weakness of the law in international negotiations, the pressure on the judicial process, the interests of non-governmental organizations, the intervention of the government system from foreign parties or interest groups, issues of human rights violations, foreign attempts to control the rule of law and so on.

Based on the identification of threat indications in the Kepulauan Riau Provincial Regional Development Plan 20162021 [13], the form of non-military threat in this dimension of law enforcement is legal morality and negative intervention to law. Thus the strategy undertaken by the Kepulauan Riau Provincial Government based on that described in the Kepulauan Riau Provincial Medium Term Development Plan 2016-2021 [13] is to carry out strategies to improve security, peace and order within the community, especially in understanding and enforcing applicable law. Programs generated based on these strategies are law enforcement programs and development programs of national insight. The main actors in the context of this strategy are Law Bureau, National Unity Board, Politics and Community Protection, Civil Service Police Unit, Ministry of Justice and Human Rights, Attorney and Regional Narcotics Board. While the supporting actors are the Indonesian National Army, the Republic of Indonesia Police and the Ministry of Defense.

\section{B. Factors affecting the Regional Development Strategy To Face Threat of Non-Military in Kepulauan Riau Province}

Based on the findings and analyzes that have been processed under the Kepulauan Riau Provincial Medium Term Development Plan 2016-2021 [13] related to the overall strategy of the Kepulauan Riau Provincial Government in regional development to face non-military threats, the Kepulauan Riau Provincial Medium Term Development Plan 2016-2021 [13] also explained the related factors supporting the regional development strategy especially in order to face non-military threats, namely:

1. Central government policy support related to the development of marine, coastal and small islands and the outer regions of Indonesia,

2. The magnitude of potential investors who have the opportunity to invest in the province of Kepulauan Riau in utilizing the potential of marine and other natural resources are quite high, including in the development of coastal tourism, sea and small islands,

3. Several areas in Kepulauan Riau Province, namely Batam, Bintan, Karimun and Tanjungpinang, as Free 
Trade Zone areas, are expected to be accelerators of industrial growth, trade and other services,

4. The regional commitment of the Asian Economic Community on the other hand is an opportunity if the products of the Micro and Small and Medium Enterprises of Kepulauan Riau Province compete in terms of quality and competitive in terms of price,

5. Potential marine and fishery resources are very large,

6. Tourism potential of the coast, the sea and the small islands that are highly prospective,

7. The potential of manufacturing industry, construction and mining and excavation is very large,

8. Potential resources of local government apparatus sufficient to support regional development and community services,

9. The advantages of local culture and the traditional values of Malay culture and art as the identity of the people of Kepulauan Riau province.

In addition to these supporting factors, the Kepulauan Riau Provincial Medium Term Development Plan 2016-2021 [13] also explains the constraining factors that will affect regional development especially in the face of non-military threats:

1. The threat of security disturbance and sovereignty in the outer regions bordering neighboring countries,

2. Implementation of the regional commitment of the Asian Economic Community, a threat to the marketing of local products,

3. Implementation of the regional commitment of the Asian Economic Community, a reference to employment opportunities for local workers,

4. The rapid advancement of information technology that can threaten the preservation of the noble values of regional culture and the morality of society,

5. Dualism of management institution of Batam City between City Government and BP Batam,

6. There are two trading systems in Kepulauan Riau Province namely the Customs area (Batam, Bintan, Karimun and some Tanjungpinang) and non-customs (Lingga, Natuna, Anambas Islands) causing trade effectiveness between districts / cities is hampered,

7. The number of poor people is quite high with decreasing performance slows from year to year,

8. The high open unemployment rate,

9. The existence of investment constraints due to the absence of the approval of the House of Representatives to be declared the Minister of Environment and Forests concerning the change of forest area has an important impact and wide coverage and strategic value (DPCLC) in Kepulauan Riau Province covering 38,872 ha.

10. The gap between the high urban / regency groups is between Batam-Tanjungpinang - Bintan - Karimun with Natuna-Anambas-Lingga,

11. The low availability and quality of land, sea, and air transportation infrastructure so that inter-regional connectivity is low,
12. The still low quality of electricity infrastructure, communication network and clean water service,

13. Human resources in agriculture are so limited that agricultural production has not been able to cover low food needs,

14. Environmental conditions degraded by exploitation of natural resources, especially mining.

\section{CONCLUSION}

The strategic issues of regional development in Kepulauan Riau Province are the things that poverty needs to be lowered, unemployment is high enough, the quality of human development is not optimal, Gender Equality and Justice Still Low, Equity and Quality of Education Still Low, Public Health Degrees Not Optimal, Quantity and Infrastructure Quality Not Adequate, Income Gap between Revenue Groups, Development of Border Areas Not Optimal, Limited Fiscal Capacity of Local Government and Governance not yet optimal, Development of Maritime and Tourism, Inter-island Connectivity and Inter District City, Vulnerability to High Food Insecurity, Optimal Preservation of Malay Culture, Pollution and Environmental Destruction and Disaster Threat. The strategic issues in the development in the Kepulauan Riau Province area give rise to indications of threats such as crime, radicalism, terrorism, social and economic gaps, knowledge gaps, apathy, human rights gaps, discriminatory social conflict, endemic or infectious diseases, IUU Fishing, illegal logging, and trafficking, illegal trading, loss of sense of nationalism and environmental damage.

The synergy of development in Kepulauan Riau Province to face the threat of non-military in order to support the implementation of state defense carried out on several areas of government affairs of Basic Service Governmental Affairs ie on Education, Health Sector, Public Works and Spatial Planning, Peace, Public Order and Protection Society, Social Sector. Then on the Non-Basic Compulsory Governmental Affairs are on the Field of Manpower, Empowerment and Child Protection Division, Food Sector, Environment Sector, Community and Village Empowerment Field, Transportation Sector, Communication and Informatics Sector, Youth and Sports Field, in Government Affairs of Choice, namely in the field of Strength and Fisheries, Agriculture Sector, and the last is on the Support of Affairs of Choice, namely in the Field of Border Management.

This synergy needs to be implemented with an action plan within the Development Planning Council. Programs and strategies integrated with non-military threats must be fully addressed by the local government which must then be integrated with the main tasks and functions of the Indonesian National Army and the Indonesian National Police as a key component of national defense. The regional government as a reserve component in the state defense system should establish an optimal synergy. Because it could be a non-military threat would threaten at any time to the local government. 


\section{ACKNOWLEDGMENT}

In conducting the research we are grateful to the Ministry of Defense which has become an important part in this study, all ranks of the military and police as well as all elements related local governments in this study. Hopefully, this study could be a particularly constructive thing to be part of regional development concept in order to confront non-military threats.

\section{REFERENCES}

[1] www.keprigov.go.id, diakses 15 September 2017

[2] www.batamtoday.com, DPRD Kepri Sepakat Perda RPJMD Kepri dari Visi Misi Nurdin Basirun. Diakses tanggal 18 Mei 2017

[3] Kementerian Pertahanan. Kerjasama Sipil dan Militer Belajar dari Tragedi Prancis. Majalah Wira Volume 57/No.41/November-Desember 2015

[4] Metrotvnews.com. Penyeludupan di Kepri Turun $80 \%$. Diakses pada tanggal 18 Mei 2017
[5] Wrihatnolo, Randy R. Nugroho, Riant. Manajemen Pembangunan Indonesia Sebuah Pengantar dan Panduan. Jakarta. Elex Media Komputindo. 2016

[6] Bastian, Indra. Sistem Perencanaan dan Penganggaran Pemerintah Daerah di Indonesia. Jakarta. Salemba Empat. 2006

[7] Badan Pusat Statistik. Tabel Input Output Indonesia 2000. Jakarta. BPS. 2003

[8] Undang-Undang No.25 Tahun 2004 tentang Sistem Perencanaan Pembangunan Nasional

[9] Undang-Undang No.3 Tahun 2002 tentang Pertahanan Negara

[10] Suryokusumo, Suryanto. Konsep Sistem Pertahanan Non Militer Suatu Sistem Pertahanan Komplemen Sistem Pertahanan Militer dalam Pertahanan Rakyat Semesta. Jakarta. Yayasan Obor Indoensia. 2016

[11] Djalil, Matori Abdul. Mempertahankan Tanah Air Memasuki Abad 21. Jakarta. Kementerian Pertahanan. 2003

[12] Materi PTP Kemenhan Provinsi Kepulauan Riau, 2017

[13] Dokumen Rencana Pembangunan Jangka Menengah Daerah (RPJMD) Tahun 2016-2021. 2017 